Ostatnia część pracy zatytułowana „Historia jako przewodnik” jest zbiorem i podsumowaniem wcześniejszych wniosków oraz zawiera pochwały pod adresem historii, która pomaga poznać samego siebie oraz zrozumieć innych ludzi. Można z niej wyciągnąć wiele cennych wniosków, acz należy pamiętać o zachowaniu ostrożności, która wynika z faktu, iż każde wydarzenie jest jedyne i niepowtarzalne.

Jak ze wszystkiego w życiu, także i z historii trzeba korzystać umiejętnie. Tak jednym zdaniem można by zamknąć rozważania MacMillan. Prawda ta może wydawać się banalna lub nazbyt oczywista, jednak obserwacja świata polityki przynosi dowody na to, że najwyżsi przywódcy często zdają się o tym zapominać. Dlatego książka MacMillan jest pożyteczną lekturą, zmuszającą do refleksji zawodowych historyków, jak i tych, którzy wybiórczo interesują się przeszłością. Jest na tyle cenną lekturą, że powinna wejść do kanonu młodych adeptów historii, aby uzmysłowić im, że historia to nie stos zakurzonych papierów, ale potężna broń, z której trzeba umieć skorzystać, Warto przypominać sobie tak często, jak to możliwe, że olbrzymia różnorodność świata, w którym żyjemy, dopuszcza mnogość jego interpretacji. Apel autorki o rozwagę w podejściu do tego, co minęło, można by dopełnić słowami angielskiego historyka Edwarda H. Carra, który sugerował, by przed rozpoczęciem studiowania historii, przestudiować samego historyka („Before you study the history, study the historian") ${ }^{2}$.

Magdalena Śnieć (Toruń)

\title{
Adrian Goldsworthy, Antony and Cleopatra, Yale University Press, New Haven \& London 2010, ss. 470
}

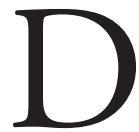

oktor Adrian Goldsworthy, brytyjski historyk specjalizujący się w dziejach rzymskiej wojskowości, jest już autorem kilku prac z tego zakresu tematycznego. Dwie spośród nich zostały przetłumaczone na język polski (In the Name of Rome. The Men Who Won the Roman Empire, London 2003 - polskie wydanie: Wimię Rzymu. Wodzowie, których zwycięstwa stworzyty rzymskie imperium, Warszawa 2004; Caesar. The Life of Colossus, London 2006 - polskie wydanie: Cezar. Życie Giganta, Warszawa 2007). Tytuł nowego historycznego opracowania Adriana

${ }^{2}$ E. H. Carr, What is History? The George Macaulay Trevelyan Lectures delivered in the University of Cambridge, January-March 1961, Londyn 1962, s. 38. 
Goldsworthy'ego: Antony and Cleopatra nawiązuje do słynnego dramatu Szekspira pod tym samym tytułem. Recenzowana książka stanowić ma z założenia szczegółowe studium politycznego i prywatnego związku rzymskiego triumwira Marka Antoniusza z hellenistyczną władczynią Kleopatrą VII. Takie ujęcie tematu nie tylko nie stanowi w nauce nowum, ale nawet wręcz przeciwnie - regułę. Jak słusznie zauważyła Ewa Wipszycka, presja literacka jest tu tak wielka, że historyk, który chciałby pominąć wątek miłosny naraziłby się na zarzut „pedanterii, małości ducha i pisarskiej nieudolności”" Trudno byłoby zatem znaleźć opracowanie, czy to naukowe, czy popularnonaukowe, którego autor nie zabrałby głosu w toczącej się od wieków debacie na temat stanu wzajemnych uczuć Marka Antoniusza i Kleopatry (podobnie jak Juliusza Cezara i Kleopatry). Być może winny jest temu sugestywnie odmalowany przez Plutarcha obraz zgubnej namiętności rzymskiego wodza z kulminacyjnym, dramatycznym momentem podczas bitwy pod Akcjum, w którym Marek Antoniusz porzuca swoich żołnierzy, by pędzić za odpływającą Kleopatrą ${ }^{2}$.

Goldsworthy zadaje dwa pytania kluczowe dla zrozumienia zagadnienia. Pierwsze dotyczy tego, czy królową Egiptu jej współcześni postrzegali jako osobę ważną - tzn. czy rzeczywiście zasłużyła sobie na tak poczesne miejsce w historii świata. Drugie pytanie dotyczy oczywiście Marka Antoniusza - jego autentycznych zdolności militarnych jako żołnierza i dowódcy armii. Na oba pytania autor odpowiada w zasadzie negatywnie. Uznaje, że brak szczegółowych informacji na temat królowej w źródłach antycznych wynika z faktu, że nie była ona postacią liczącą się na ówczesnej arenie międzynarodowej, co oczywiście wiązało się z polityczną pozycją Egiptu od dawna zagrożonego rzymską aneksją. Narzuca się tu zatem porównanie - choć nie czyni tego Goldsworthy - ze Spartakusem, który z przywódcy niewolniczego powstania, stłumionego w zasadzie bez wielkich trudności, wyrósł na symbol bohaterskiej walki wyzwoleńczej, stając się bohaterem literackim i filmowym, czym starożytni Rzymianie byliby niewątpliwie zdumieni³ ${ }^{3}$ Jeśli chodzi o Marka Antoniusza w roli wodza, to w opinii Goldsworthy'ego nie był on wybitnym strategiem, wręcz przeciwnie - w zasadzie więcej bitew przegrał niż zakończył sukcesem. Został pobity w 43 r. p.n.e. i jedynie manewry polityczne wykreowały go na triumwira. Wyolbrzymia się jego sukces pod Filippi. Inwazja na Medię okazała się katastrofą z powodu licznych błędów, które popełnił. Wreszcie pod Akcjum w 31 r. p.n.e. pozostawił wrogowi militarną inicjatywę i jego jedynym sukcesem było przełamanie morskiej blokady. Zatem publiczny wizerunek Marka Antoniu-

${ }^{1}$ E. Wipszycka, Historia starożytnych Greków, t. 3, Warszawa 1992, s. 219.

2 Plut. Ant. 66.

3 Zob. krótko na temat fenomenu Spartakusa: W. Schuller, Wprowadzenie do studium historii starożytnej, Warszawa 1997, s. 110-112. 
sza jako dobrego żołnierza i zdolnego wodza jest jedynie mitem. Oktawian i Agryppa zwyciężyli, ponieważ przewyższali Antoniusza militarnie, a zatem nie uległość względem Kleopatry, czy ostrze wrogiej propagandy stało się powodem jego porażki. Goldsworthy sądzi, że to raczej dramatyczne okoliczności śmierci Antoniusza i Kleopatry legły u podstaw niezwykłej sławy, która otacza tę parę, niźli ich polityczne i militarne znaczenie dla dziejów świata. W zasadzie jedynym sukcesem Kleopatry było utrzymanie się przy władzy przez dwadzieścia lat. Królowa nie przeciwstawiła się Rzymowi, ale akceptowała jego władzę i próbowała zrobić z niej użytek. Trzeba pamiętać, że Kleopatra, podejmując rokowania z Juliuszem Cezarem, stanęła po stronie najeźdźcy i to określiło jej dalsze poczynania polityczne. Marek Antoniusz i Kleopatra - jak pisze Goldsworthy - byli przede wszystkim zwierzętami politycznymi (Antony and Cleopatra were first and foremost political animal) i chyba nie należy traktować tego jako pochlebstwa pod ich adresem.

Spore objętościowo dzieło Goldsworhy'ego, bo liczące 470 stron, ma układ chronologiczny. Autor nie zamyka jednak rozważań w przedziale czasowym 41-30 p.n.e., czyli okresie aliansu bohaterów, ale sięga głębiej, przedstawiając dzieje politycznego i prywatnego mariażu Kleopatry i Cezara, historię ptolemejskich przodków królowej oraz całą karierę triumwira. Kolejne rozdziały naprzemiennie prezentują egipską oraz rzymską część historii do roku 41 p.n.e., kiedy to dochodzi do połączenia opowieści w jedną całość.

Praca Goldsworthy'ego zdobiona ilustracjami i mapami jest niewątpliwie napisana sumiennie. Autor powołuje się na dostępną anglojęzyczną literaturę przedmiotu. Rodzi się oczywiste pytanie, czy praca ma charakter nowatorski. Jeśli chodzi o Kleopatrę, autor w zasadzie nie powiedział nic nowego. Obraz Kleopatry odgrywającej istotną rolę w polityce ówczesnego świata poddawany jest ciągłej krytyce, co w żadnej mierze nie wpływa na jej popularność jako bohaterki książek naukowych. Jednakże w powstających nieustannie nowych biografiach władczyni autorzy rozpatrują teraz w większym stopniu królową w aspekcie egipskim niźli międzynarodowym ${ }^{4}$. Niewątpliwie ciekawsza może być próba odarcia Marka Antoniusza z żołnierskiej chwały, ponieważ jego imię nierozłącznie kojarzy się z polem bitwy i żołnierskim stylem bycia.

W sumie książka jest pesymistyczna w wymowie, jeśli tak można powiedzieć o pracy naukowej, z czego zdaje sobie sprawę sam autor, wyrażając na koniec nadzieję, że ciała Kleopatry i Marka Antoniusza nigdy nie zostaną odnalezione i nie spoczną jako eksponaty w muzeum, co pozwoli trwać legendzie.

\section{Lucyna Kostuch (Kielce)}

${ }^{4}$ Np. A.-S. Ashton, Cleopatra and Egypt, London 2008; J. Tyldesley, Cleopatra. Last Queen of Egypt, New York 2008. 